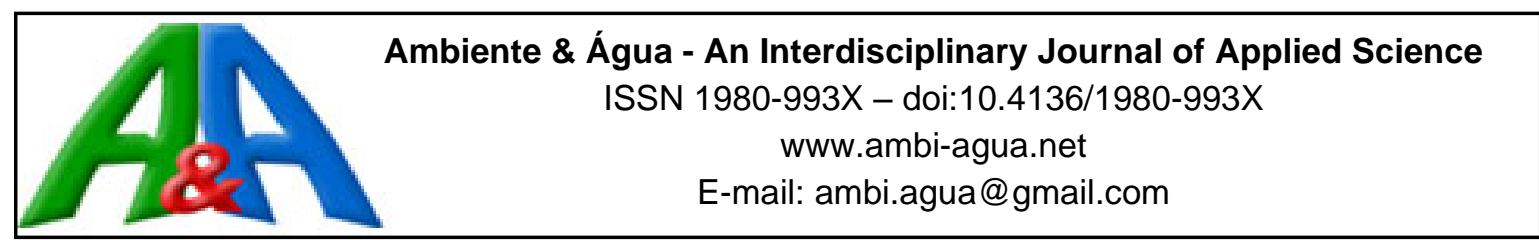

\title{
Geochemistry water of the Camaquã das Lavras and Hilário streams, Lavras do Sul-RS: anthropogenic or natural?
}

\author{
ARTICLES doi:10.4136/ambi-agua.2445
}

Received: 16 Jul. 2019; Accepted: 13 Dec. 2019

\section{Cristiane Heredia Gomes $^{1 *}$; Arthur Pedroso Viçozzi ${ }^{1}$; ; Guilherme Pazinato Dias ${ }^{1}$; Diogo Gabriel Sperandio 1 ib}
${ }^{1}$ Departamento de Geologia. Universidade Federal do Pampa (UNIPAMPA), Avenida Pedro Anunciação, n 111, CEP: 96570-000, Caçapava do Sul, RS, Brazil. E-mail: arthurvicozzi@gmail.com, gui.pazinato.dias@gmail.com, gabrielspe@gmail.com
*Corresponding author. E-mail: cristianegomes@unipampa.edu.br

\begin{abstract}
This article presents the first detailed geochemical data of the water from Camaqua das Lavras and Hilário Streams from Lavras do Sul-RS. Geochemical and statistical analyses were used in this study to establish the anthropogenic or natural influence on the region. The results classified the waters as soft and intermediate with acidic and neutral $\mathrm{pH}$. The electrical conductivity varies from 37.2 to $62.9 \mu \mathrm{sm}^{-1}$ and the total alkalinity ranges from 4 to $30 \mathrm{mgL}^{-}$ 1 . The distribution patterns and ratios indicate that clay mineral weathering is dominant on the investigated samples. It is followed by feldspar weathering in an environment under temporary hardness conditions. $\mathrm{Cu}, \mathrm{Rh}$, and $\mathrm{Cd}$ enrichment is associated with the many mineral deposits of the region, lithological diversity and human activities. All the measured values conform with the standards set by Brasil-Ordinance nos. 2914/2011, 36-GM/1990 and 1469/2000.
\end{abstract}

Keywords: geostatistics, hydrochemistry, water resources.

\section{Geoquímica da água dos arroios Camaquã das Lavras e Hilário, Lavras do Sul-RS: Antropogênico ou natural?}

\section{RESUMO}

Este artigo apresenta os primeiros dados geoquímicos de detalhe da água dos arroios Camaquã das Lavras e Hilário, Lavras do Sul-RS. Neste estudo foram utilizadas análises geoquímicas e geoestatísticas para estabelecer as influências antropogênicas ou naturais na região. Os resultados permitiram classificar as águas como mole e intermediária com $\mathrm{pH}$ ácido e neutro. A condutividade elétrica variou de 37.2 a $62.9 \mu \mathrm{s} \mathrm{cm}^{-1}$ e a alcalinidade total entre $4 \mathrm{e}$ $30 \mathrm{mg} \mathrm{L}^{-1}$. Razões e padrões de distribuição indicam que o intemperismo de argilominerais é dominante nas amostras investigadas. Seguido pelo intemperismo do feldspato em ambiente sob condições de dureza temporária. O enriquecimento de $\mathrm{Cu}, \mathrm{Rh}$ e $\mathrm{Cd}$ é associado à depósitos minerais da região, à diversidade litológica e às atividades humanas. Todos os valores medidos atendem aos padrões estabelecidos pelas Portarias-Brasil $n^{\text {s}_{5}} 2914 / 2011,36-\mathrm{GM} / 1990$ e $1469 / 2000$.

Palavras-chave: estatística, hidroquímica, recursos hídricos. 


\section{INTRODUCTION}

Concern about possible forms of environmental contamination is a constant theme in global debates. Among the forms of environmental pollution, anthropic pollution stands out. Anthropic pollution has become one of the main aggravating polluters and this reflects the illogical behavior of humans. It generates irreversible effects on the environment and on human health. Thus, one of the points of view that concerns most of the researchers is water contamination. In Brazil, the quality of water is protected by specific environmental legislation, based on principles of the Brazilian Federal Constitution of 1988, which declares that "[...] Everyone has the right to an ecologically balanced environment, good for the common use of the people and essential to the quality of healthy life [...]" (Brasil, 1990, p. 127).

Water's chemical composition is intimately related to its quality standards, allowing the parameters of classification and use, such as human consumption, agriculture, livestock, among others (Steffens et al., 2015). Several factors can influence water composition, such as climate, anthropogenic contamination (progressive urban occupation, increased industrial processes, mining activities and the distribution of urban waste) and lithologies related to each region.

On the other hand, water quality also depends on the geological environment. The chemical elements available in the primary geochemical environment (chemical elements on the mineralogical structure of the minerals that compose the rocks) spread into secondary environments, soil, water, and sediments (Batista, 2003). The decomposition and desegregation of the rocks by weathering processes occur on the continental crust surface. Weathering is the interaction between the distinct terrestrial layers (lithosphere, atmosphere, hydrosphere, and biosphere) changing the rocks to transportable materials.

The weathering process disaggregates and turns the rocks into fragments, modifying their composition, decomposing the most fragile minerals and forming new ones. Weathering may cause chemical or physical transformations, or a combination of both, with or without anthropic influence (Cheremisinoff, 1997).

The contact of water with rocks promotes chemical reactions, carrying dissolved substances along its way. The result of these reactions will be a collection of secondary minerals. According to Cheremisinoff (1997), the main reactions that occur during chemical weathering are hydration, hydrolysis, oxidation, and complexation.

Hydration is the insertion of water into the chemical structure of a mineral, causing its weakness and forming another mineral. Oxidation occurs with all minerals that have elements that can suffer oxidation, such as iron, for example. The complexation is a reaction that involves organic compounds dissolved in water, which poorly retain soluble chemical elements in their structure, mobilizing them. Hydrolysis is the most important reaction of chemical weathering. It destroys the mineral structure and makes cations and anions available in the water. According to Bakalowicz (1994), the most important soluble salts occurring in relatively substantial amounts in the rocks are carbonates and chlorides, and the most relevant ions found in the waters are $\mathrm{Ca}^{2+}, \mathrm{Mg}^{2+}, \mathrm{Na}^{+}, \mathrm{Cl}^{-}, \mathrm{SO}_{4}{ }^{2-}$ and $\mathrm{HCO}_{3}$. Alkaline and alkaline-earth metals are dissolved by water and removed. The less soluble $\mathrm{Ca}$ and $\mathrm{Mg}$ carbonates are dissolved in the presence of $\mathrm{CO}_{2}$ in the water.

As water penetrates the soil and the rocks, it leaches components and becomes enriched in mineral salts originated by the dissolution and oxidation of the rocks. The dissolution process is influenced by the $\mathrm{pH}$, temperature and saturation degree of each element (Steffens et al., 2015). The chemical characteristics of water reflect the water circulation zone, showing a close relationship with the percolated rocks types and the products of anthropic activities added in the water along this circulation path.

Therefore, environmental monitoring is a primary need in the context of maintaining a population's quality of life, paying attention to the urbanization growth rate and consequently, 
environmental degradation. When evaluating the quality of an urban environment, water reveals the integration of biological, physical and chemical processes that occur in an aquatic ecosystem. Thus, the study of these individual or grouped processes may be used to detect the presence of contaminants in the environment.

This work involved the geochemical and statistics analysis of the water samples from Camaquã das Lavras and Hilário Streams, in the rural area of Lavras do Sul/ RS. This work characterizes the water quality of streams and determines whether the geochemical influence in the water is anthropic or natural. To detect and evaluate metals in the investigated waters in a simple, fast and inexpensive way, the Energy Dispersive X-ray Fluorescence (EDXRF) was used (Wastowski et al., 2010). Principal component analysis was also used to help identify the close relationship between sample/variables (Lawrence and Upchurch, 1982). Multivariate statistical analysis has been successfully applied in numerous hydrochemical studies, in which it has helped to simplify and organize a large amount of data and show the anthropic impact and/or investigate water contamination (Gomes et al., 2018a; 2018b).

\subsection{Studied Area}

The Camaquã das Lavras and Hilário Streams are located in the Rio Grande do Sul State of Brazil, in Lavras do Sul, at the coordinates 3048'46 "S and 53॰53'42 "W (Figure 1). Access to the area is by highway Br-392 and then by Rs-357, $2.5 \mathrm{~km}$ from the secondary access, to the west towards Caçapava do Sul-Lavras do Sul. The studied area was strategically chosen due to its susceptibility mainly to urban waste contamination and its proximity to mining areas.

The Lavras do Sul District has been known since the nineteenth century for exhibiting great lithological diversity and significant metallogenic importance (Pestana and Formoso, 2003). The region is characterized by the occurrence of base metal mineralization associated with sulfides, gold, copper, lead, zinc and silver (Lopes, 2013). The district concentrates $\sim 70 \%$ of the mining companies that are active in the area of Camaqua watershed, which includes the investigated Camaquã das Lavras and Hilário Streams (High Camaquã Streams watershed).

Camaquã das Lavras Stream and its tributaries flow near the urban center, being classified as Class 4 (Brasil-Ordinance $N^{\text {os }}$. 206/2016). In the sample collecting points, the transported sediments show a wide variety, including iron hydroxide, aluminum hydroxide, clay, silt and sand. The Hilário Stream, is located east of the Lavras do Sul urban center and was classified as Class 1 (Brasil-Ordinance $\mathrm{N}^{\text {os }}$. 206/2016). The sampled stretch the stream presents the highest flow speed. There is almost no alluvial plain (flood) as the stream extends for approximately the entire valley.

Regarding the composition and formation of the vegetative cover, it is essentially composed of shrubs and small- to medium-sized spaced trees. Hilly grasslands geomorphologically characterize the relief, also demarcated by a soft, slightly steep low slope. Granitic and acidic volcanic rocks characterize the bedrock of the Lavras do Sul Intrusive Complex and the Hilario Formation. The soil originated from the degradation of these rocks shows certain variations. In the uplifted topography portions, the soil exhibits a sandy-silt texture and orange coloring, marked by iron oxides and hydroxides (hematite and limonite). In the lower topography portions, the ground has more sandy textures and dark brown colors. Higher organic matter content in the soil, as well as the concentration of leached chemical elements of the higher portions, may explain the color change.

The Lavras do Sul Intrusive Complex is a circular body with $216 \mathrm{~km} 2$ (Figure 1) formed by Monzodiorite, Monzogranite, Quartz Monzonite and Petite Granite facies (Gastal et al., 2015). This body has intrusive behavior in orthogneiss and pre-and non-tectonic granitoid in W-SW and N-NW portions. S-SE is delimited by the São Rafael Formation, whose contact is controlled by the fault zone with direction NE-SW, named São Domingos, and to the East by the Hilário Formation (Ribeiro et al., 1966). These two formations are overlapped in an angular 
disagreement, which represents the basal units of the Camaquã Basin (Porcher and Lopes, 2000). The deposit configuration of the area is known to fit into the copper porphyrin system, in which porphyrins igneous rocks subjected to intense hydrothermal processes end up enriched in sulfides.

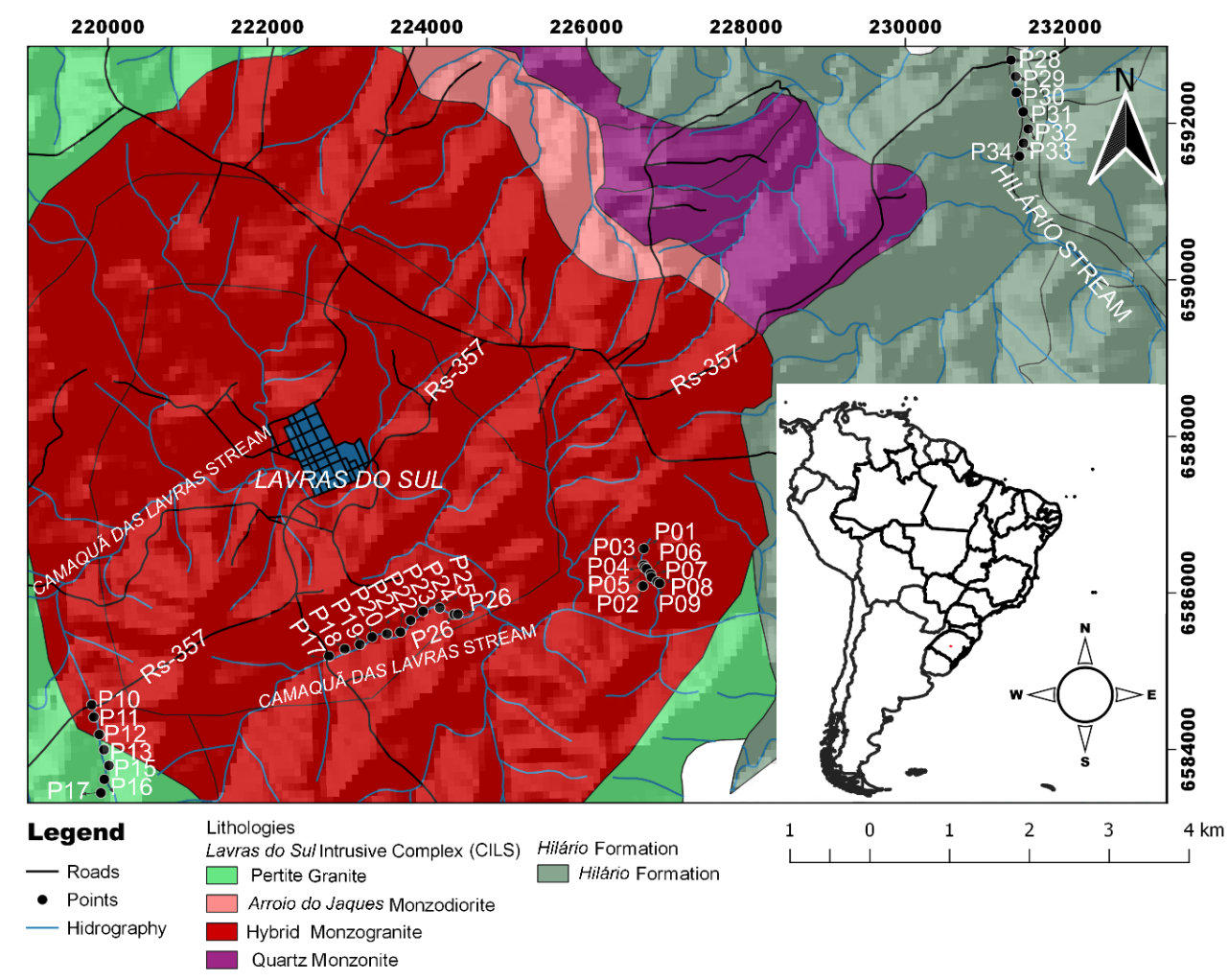

Figure 1. Geological map of the Lavras do Sul region with the location of the points. On the right, the graphical representation of South America, with Lavras do Sul highlighted (red point).

The mineralogy of this granitoids is composed of alkali feldspar $\left(\mathrm{KNaAlSi}_{3} \mathrm{O}_{8}\right)$ with alteration to white mica and iron oxides (hematite), plagioclase $\left.(\mathrm{Ca}, \mathrm{Na}) \mathrm{Al}(\mathrm{Al}, \mathrm{Si}) \mathrm{Si}_{2} \mathrm{O}_{8}\right)$ with alteration to kaolinite $\left(\mathrm{Al}_{2} \mathrm{Si}_{2} \mathrm{O}_{5}\left(\mathrm{OH}_{4}\right)\right)$ and/or gibbsite $\left(\mathrm{Al}(\mathrm{OH})_{3}\right)$, biotite $\left(\mathrm{K}_{2}\left(\mathrm{Mg}, \mathrm{Fe}^{2+}\right)_{6-}\right.$ ${ }_{4}\left(\mathrm{Fe}^{3+}, \mathrm{Al}, \mathrm{Ti}\right)_{0-2} \mathrm{Si}_{6-5} \mathrm{Al}_{2-3} \mathrm{O}_{20}(\mathrm{OH}, \mathrm{F})_{4}$ with alteration for reddish and black metallic oxides, quartz $\left(\mathrm{SiO}_{2}\right)$ and oxides. The accessory minerals are hornblende $\left(\mathrm{Ca}_{2} \mathrm{Na}(\mathrm{Mg}, \mathrm{Fe})_{4}(\mathrm{Al}, \mathrm{Fe}, \mathrm{Ti})\right.$ $\left.\mathrm{AlSi}_{8} \mathrm{AlO}_{22}(\mathrm{OH}, \mathrm{O})_{2}\right)$, pyroxene $(\mathrm{Ca}, \mathrm{Na})(\mathrm{Mg}, \mathrm{Fe}, \mathrm{Al}, \mathrm{Ti})\left(\mathrm{Si}_{2} \mathrm{O}_{6}\right)$, zircon and apatite. Over the outcrops an occurrence of differential alterations in the rocks is observed. A sign of these changes is the filling of rock fractures and the occurrence of euhedral quartz of $0.5 \mathrm{~cm}$ long. Beside this are pervasive iron oxide films (hematite) and generalized alterations to sericite and white mica. This describes the change processes responsible for claylization, chloritization and carbonation in the rocks.

Around the Lavras do Sul Intrusive Complex two formations may be observed: São Rafael and Hilário (Figure 1). The São Rafael Formation includes arcosean to subarcoseans sandstones, intercalated with conglomerate sandstones (Porcher and Lopes, 2000). The Hilário Formation is composed of effusive facies with porphyritic andesites and volcaniclastic facies and auto breccias composed of porphyritic andesite fragments (de Liz et al., 2009). In the studied area, porphyritic andesites of dark-gray to reddish staining were found, due to the strong alteration. The andesites show a porphyritic texture, characterized by euhedral plagioclase phenocrystals up to $2.0 \mathrm{~cm}$ (around 30\%), and rare $(<5 \%)$ augite phenocrystals immersed in an aphanitic matrix composed mainly of plagioclase. In some specimens, opaque minerals are present. The accessory minerals are zircon and apatite. They show a strong alteration in almost 
all samples, evidenced by the presence of alteration minerals such as chlorite $(\mathrm{Mg}, \mathrm{Al}, \mathrm{Fe})_{12}(\mathrm{Si}, \mathrm{Al})_{8} \mathrm{O}_{20}$, carbonates $\left(\mathrm{CaCO}_{3}\right.$ - calcite; $\mathrm{MgCO}_{3}$ - dolomite) and white mica (like muscovite $\left.-\mathrm{KAl}_{2} \mathrm{Si}_{3} \mathrm{AlO}_{10}(\mathrm{OH}, \mathrm{F})_{2}\right)$. Resorption features such as corrosion are common in most crystals, in addition to change processes responsible for the claylization, chloritization and carbonation at the edges and cores of the minerals. A moderate fracture degree may be observed in the grains that contributes to the alteration and oxidation processes, besides a filling of postmagmatic silica.

\section{MATERIALS AND METHODS}

A total of 33 samples were collected at the end of April 2018 (Figure 1), twenty-seven along the Camaquã das Lavras Stream (samples P1 a P27) and six along the Hilário Stream (samples P28 a P33). The sampling area was strategically selected due to the concentration of mining areas and because it reflects the conditions of the environment under anthropic and lithological influence. One half liter of water samples was collected in polyethylene bottles. The bottles were previously decontaminated with nitric acid (10\%) for 48 hours and washed with distilled water and taken to an oven to dry $\left(25^{\circ} \mathrm{C}\right)$, according to FUNASA (2006). They were then sealed and brought to the Chemistry and Mineralogy/Petrography Laboratories (LMP - UNIPAMPA University). All samples were preserved and analyzed within seven days of the date of collection, according to ABNT (1992) and FUNASA (2006). Immediately after the samples had been collected, the $\mathrm{pH}$ was checked by using a pHmeter at the laboratory. The electric conductivity of the samples was measured by a GEHAKA CG1800 apparatus. To determine the hardness of the samples, the EDTA served as titrant and the eriochrome-T as an indicator (APHA et al., 2005; ABNT, 1992). The blank reagent titration was done simultaneously using distilled/deionized water.

Approximately $50 \mathrm{ml}$ of water was isolated from each sample for the elemental analysis by Energy Dispersive X-ray Fluorescence (EDXRF), Model S1 Turbo SD. The chemical elements and quantities in the water were analyzed at the Laboratory of Mineralogy and Petrography (LMP-Unipampa). The following equipment conditions were selected: tube voltage of $15 \mathrm{keV}$ ( $\mathrm{Na}$ to $\mathrm{Sc}$ ) and $50 \mathrm{keV}$ (Ti to U), with a current in the tube of 184 and $25 \mu \mathrm{A}$, respectively; $10 \mathrm{~mm}$ collimator; $120 \mathrm{~s}$ of real-time integration. The equipment uses an $\mathrm{Ag}$ anode, which allows the measuring of 25 elements, and a detector of $10 \mathrm{~mm}^{2}$ with thermoelectric cooling and resolution of $\sim 145 \mathrm{eV}$ to $\mathrm{MnK} \alpha$ that maintains a speed of 100.000 counts per second (Bona et al., 2007; Teixeira et al., 2017).

In this study, the Principal Component Analysis (PCA) method was used as a multivariate statistical technique, commonly used to investigate the variability in large geochemical data sets (Linhai Jing and Panahi, 2006; Scheib et al., 2011). The analysis of correlations and main components were carried out using Statistical Package Statsoft Version 10. PCA is a variable reduction method that produces a smaller number of artificial variables, known as main components (PCs). Each PC represents a certain amount of variability in the data, and the first two PCs usually show the most variations within the entire data group (Reimann et al., 2008).

\section{RESULTS AND DISCUSSION}

The hydrochemical characteristics of the studied water samples reflect the reactions involving sulfates, carbons, chlorides, alkali metals, alkaline-earth and $\mathrm{CO}_{2}, \mathrm{O}_{2}$ and $\mathrm{S}$. The water samples from Camaquã das Lavras Stream were separated into different geographical groups: Group 1, composed of samples P10 to P16; Group 2, formed by samples P17 to P27; and Group 3, samples P1 to P9 (Figure 1). The Hilário Stream samples were treated as a single and comparative group to the Camaquã das Lavras Stream samples. The results of the analyses are presented in Tables 1, 2, 3, 4 and 5. 
All pH samples were between 5.47 and 6.72 (Table 1), classified as acidic water or close to neutral. In the Camaquã das Lavras Stream, the $\mathrm{pH}$ samples varied between 5.71 and 6.72, and in the Hilário Stream, the $\mathrm{pH}$ varies from 6.12 to 6.35. The $\mathrm{pH}$ value is also a relevant result to the composition of the water quality indices, being a potability pattern. Thus, the majority of the measured values of $\mathrm{pH}$ for investigated samples are within the standards established by Ordinance No. 206 (Conselho de Recursos Hídricos, 2016). The recommended pH values should be 6.0 and 9.5. Exception samples showed $\mathrm{pH}<6.0$ (Table 1), for example, in Group 3, the samples P1 (5.71) and P2 (5.94), and in Group 1 the samples P10 (5.89), P11 (5.96), P14 (5.94), P15 (5.61) e P16 (5.47). In these cases, the presence of free $\mathrm{CO}^{2}$, and acids derived from the mineral alterations (e.g. boric acid, hydrochloric, nitric or sulfuric) may be present. They release hydrogen ions to the system and/or organic compounds as a result of synthetic activities of plants and animals (Steffens et al., 2015).

The alkalinity variation was between 4 and $30 \mathrm{mlL}^{-1}$ of $\mathrm{CaCO}_{3}$ (Table 1), which is equivalent to water resources of freshwater (FUNASA, 2006). The Camaquã das Lavras Stream presented the highest alkalinity values, ranging from 4 to $28 \mathrm{mg} \mathrm{L}-1$. In Group 1, the alkalinity ranged from 22 to $28 \mathrm{mg} \mathrm{L}-1$; in Group 2, the measured values were from 22 to 30 $\mathrm{mg} \mathrm{L}^{-1}$; and in Group 3 (samples P1 to P9), the alkalinity varied between 4 to $8 \mathrm{mg} \mathrm{L}-1$. In the Hilário Stream, the alkalinity oscillated between 12 to $24 \mathrm{mg} \mathrm{L}^{-1}$ (Table 1). The total alkalinity is directly associated with the processes of chemical weathering (partial or total hydrolysis) and the capacity of water or components tamponade of an effluent (Piveli and Kato, 2006). Alkalinity can indicate three causes: 1) hydroxide and bicarbonate alkalinity; 2) alkalinity of hydride, and 3) carbonate alkalinity. The variation of the values obtained in the analyzed waters suggests possibly varying degrees of carbonates or salts of $\mathrm{Na}, \mathrm{K}$ and $\mathrm{Mg}$ dissolved in water by passage through soil or rock substrate.

The electrical conductivity (EC) of the analyzed samples ranged from 48.2 to $66 \mu \mathrm{S} . \mathrm{cm}^{-1}$ (Table 1), with this variation being an indirect measure of the pollutant concentration. Levels above $100 \mu \mathrm{S} / \mathrm{cm}^{3}$ indicate environmental impacts and corrosive water characteristics, but do not indicate the relative quantity of the various components (CETESB, 2016). Higher EC values were found in waters of the Hilario Stream samples, ranging from 60.4 to $62.9 \mu \mathrm{S} / \mathrm{cm}^{3}$. The lowest values were obtained for the waters of the Camaquã das Lavras Stream. In Group 1, the EC values ranged from 37.2 to $53.5 \mu \mathrm{S} / \mathrm{cm}^{3}$; in Group 2 ranged from 48.2 to $66 \mu \mathrm{S} / \mathrm{cm}^{3}$; and in Group 3 is between 41.6 and $50.9 \mu \mathrm{S} / \mathrm{cm}^{3}$. The EC can be classified as Type I if the enrichment of salts is $<1.500 \mu \mathrm{S} / \mathrm{cm}^{3}$; Type II, if the enrichment of salts is between 1.500 and 3.000 $\mu \mathrm{S} / \mathrm{cm}^{3}$; and Type III, if salts enrichment is $>1.500 \mu \mathrm{S} / \mathrm{cm}^{3}$ (SubbaRao et al., 2012). Thus, the waters of both studied streams can be classified as Type I, showing an increasing trend along Group $3<1<2$ and $<$ Hilário Stream. Coincidentally, the most acidic $\mathrm{pH}$ is noticed in the water samples of Group 1, < Hilário Stream, $<3$ and $<2$.

The total hardness results of the samples showed elevated variation, with values between 14.29 and $88.77 \mathrm{mg} \mathrm{L}^{-1}$ of $\mathrm{CaCO}_{3}$ (Table 1), allowing the classification of these waters between soft and intermediary (Sawyer et al., 2000). The data presented corroborate the hardness ratings for urban and rural waters of Rio Grande do Sul State and Brazil (Steffens et al., 2015; Gomes et al., 2017; 2018a; 2018b), and are within the standards of Ordinance $\mathrm{N}^{\circ} \cdot 1469$ (Anvisa, 2001).

The main origin associated with total hardness in water bodies is the dissolution of rocks with minerals rich in $\mathrm{Ca}$ and $\mathrm{Na}, \mathrm{K}$ and $\mathrm{Mg}$ elements due to reactions with $\mathrm{CO}_{2}$ present in water. This property can be quantified when water is in contact with $\mathrm{HCO}^{3-}, \mathrm{SO}_{4}, \mathrm{NO}_{3}$ and $\mathrm{Cl}$ (Pivelli, 2014), being classified as temporary or permanent (Pereira et al., 2010). The temporary hardness is due to the presence of $\mathrm{CaCO}_{3}$ and $\mathrm{Mg}$ that, by heat action, break down to $\mathrm{CO}_{2}$, and precipitate insoluble carbonates. The permanent hardness reflects the presence of $\mathrm{SO}_{4}, \mathrm{Cl}$ e $\mathrm{Ca}$ $\left(\mathrm{NO}_{3}\right)_{2}$ e $\mathrm{Mg}\left(\mathrm{NO}_{3}\right)_{2}$. This hardness also resists the action of soaps, but does not produce encrustations since its salts are highly soluble in water and do not decompose in heat. 
Table 1. Results obtained in tests for the total hardness, $\mathrm{pH}$, conductivity, total alkalinity, calcium, magnesium and temperature determinations.

\begin{tabular}{|c|c|c|c|c|c|c|c|c|c|c|}
\hline & & Samples & $\begin{array}{l}\text { Total alkalinity } \\
\qquad\left(\mathrm{mg} \mathrm{L}^{-1}\right)\end{array}$ & $\begin{array}{c}\text { EC } \\
\left(\mu \mathrm{cm}^{-1}\right)\end{array}$ & Temperature $\left({ }^{\circ} \mathbf{C}\right)$ & $\begin{array}{l}\text { Calcium } \\
\left(\mathrm{mg} \mathrm{L}^{-1}\right)\end{array}$ & $\begin{array}{l}\text { Total hardness } \\
\left(\mathrm{mg} \mathrm{L}^{-1} \mathrm{CaCO}_{3}\right)\end{array}$ & Classification of hardness & $\mathbf{p H}$ & $\begin{array}{l}\text { Magnesium } \\
\quad\left(\mathbf{m g ~ L}^{-1}\right)\end{array}$ \\
\hline \multirow{26}{*}{ Camaquã das Lavra Streams } & \multirow{9}{*}{ Group 3} & P1 & 6 & 50.9 & 13.3 & 40.90 & 70.41 & Soft & 5.71 & 24.45 \\
\hline & & P2 & 4 & 49 & 15.1 & 40.90 & 76.53 & Medium hard & 5.94 & 24.48 \\
\hline & & P3 & 6 & 48 & 17.4 & 40.90 & 58.16 & Soft & 6.66 & 24.37 \\
\hline & & P4 & 6 & 44.3 & 16 & 44.99 & 42.86 & Soft & 6.72 & 24.16 \\
\hline & & P5 & 4 & 43.5 & 20.02 & 44.99 & 56.12 & Soft & 6.52 & 24.31 \\
\hline & & P6 & 6 & 45.4 & 19.8 & 40.90 & 50.00 & Soft & 6.45 & 24.30 \\
\hline & & P7 & 8 & 45.6 & 17 & 49.08 & 37.75 & Soft & 6.55 & 24.00 \\
\hline & & P8 & 4 & 41.6 & 19.1 & 40.90 & 66.33 & Soft & 6.61 & 24.42 \\
\hline & & $\mathrm{P} 9$ & 4 & 41.6 & 19.9 & 44.99 & 60.20 & Soft & 6.65 & 24.34 \\
\hline & \multirow{7}{*}{ Group 1} & P 10 & 22 & 52.7 & 8.9 & 61.35 & 81.63 & Medium hard & 5.89 & 24.34 \\
\hline & & P 11 & 28 & 53.5 & 10 & 53.17 & 86.73 & Medium hard & 5.96 & 24.43 \\
\hline & & P 12 & 24 & 49.7 & 10.7 & 65.44 & 81.63 & Medium hard & 6.1 & 24.31 \\
\hline & & P 13 & 28 & 46.2 & 10.7 & 61.35 & 85.71 & Medium hard & 6.12 & 24.36 \\
\hline & & P 14 & 26 & 43 & 10.2 & 61.35 & 71.43 & Soft & 5.94 & 24.27 \\
\hline & & P 15 & 28 & 40.2 & 9.3 & 89.97 & 82.65 & Medium hard & 5.61 & 24.13 \\
\hline & & P 16 & 26 & 37.2 & 10.6 & 77.71 & 82.65 & Medium hard & 5.47 & 24.22 \\
\hline & \multirow{10}{*}{ Group 2} & P 17 & 28 & 53.8 & 11 & 53.17 & 80.61 & Medium hard & 6.19 & 24.40 \\
\hline & & P 18 & 28 & 48.2 & 11 & 73.62 & 14.29 & Soft & 6.32 & 21.62 \\
\hline & & P 19 & 24 & 52.8 & 11.5 & 69.53 & 27.55 & Soft & 6.38 & 23.24 \\
\hline & & P 20 & 30 & 53.4 & 11.4 & 77.71 & 32.65 & Soft & 6.42 & 23.33 \\
\hline & & P 21 & 28 & 53.2 & 10.6 & 65.44 & 38.78 & Soft & 6.48 & 23.76 \\
\hline & & P 22 & 26 & 53 & 10.4 & 69.53 & 40.82 & Soft & 6.47 & 23.75 \\
\hline & & P 23 & 26 & 53.1 & 10.1 & 73.62 & 51.02 & Soft & 6.58 & 23.91 \\
\hline & & P 24 & 28 & 49.3 & 10.5 & 85.89 & 48.98 & Soft & 6.56 & 23.72 \\
\hline & & P 25 & 28 & 51.5 & 11.2 & 89.97 & 61.22 & Soft & 6.6 & 23.90 \\
\hline & & P 26 & 28 & 49.6 & 12 & 3.68 & 47.96 & Soft & 6.31 & 20.06 \\
\hline \multirow{7}{*}{ Hilário Stream } & & P27 & 22 & 66 & 9.2 & 2.45 & 36.73 & Soft & 6.4 & 20.67 \\
\hline & & P28 & 20 & 62.4 & 7.4 & 2.86 & 61.22 & Soft & 6.12 & 21.91 \\
\hline & & P29 & 12 & 61.8 & 10.1 & 2.86 & 61.22 & Soft & 6.17 & 21.91 \\
\hline & & P30 & 10 & 62.9 & 8.4 & 2.45 & 52.04 & Soft & 6.45 & 21.89 \\
\hline & & P31 & 24 & 60.4 & 10.5 & 2.86 & 64.29 & Soft & 6.35 & 22.05 \\
\hline & & P32 & 16 & 62.1 & 10 & 2.86 & 45.92 & Soft & 6.33 & 20.95 \\
\hline & & P33 & 14 & 61.9 & 8.8 & 2.45 & 88.77 & Medium hard & 6.26 & 23.10 \\
\hline
\end{tabular}


The Ca quantity oscillated from a minimum of $2.45 \mathrm{mg} \mathrm{L}^{-1}$ (sample P27) to a maximum of $89.97 \mathrm{mg} \mathrm{L}^{-1}$ (samples P 15 and P 25; Table 1). The Mg presented low-amplitude variation with values between 20.06 and $24.48 \mathrm{mg} \mathrm{L}^{-1}$.

Figure 2 shows the value variation between $\mathrm{Ca}$ and $\mathrm{Mg}$ in relation to the total hardness measured in the investigated water samples. The variation of the $\mathrm{Ca}$ value in relation to the three sampling groups of the Camaquã das Lavras and the Hilário Streams is clear. The samples are randomly distributed and it is not possible to suggest positive or negative correlations.

The equations in Figure 2 show that the total hardness coefficient in Ca of Groups 1, 2 and 3 from Camaqua das Lavras Stream is $0.1129,0.0391$ and $0.1707 \mathrm{mg} \mathrm{L}^{-1}$, respectively. In the Hilário Stream, the total hardness coefficient in $\mathrm{Ca}$ tends to zero. The most significant correlation was found between the total hardness and the $\mathrm{Ca}$ ions of the water samples in Group $3(\mathrm{r}=52 \%$; Figure 2); however, the correlation obtained between the total hardness and the $\mathrm{Mg}$ ions for all water samples was $r=20 \%$ (Figure 2). This suggests that the water hardness of Group 3, probably, is a direct influence of the mineralogical composition of granitoids (Lavras do Sul Intrusive Complex) and volcanic rocks. The $\mathrm{Mg}$ is associated with iron-magnesium minerals of granitoids and volcanic rocks, such as pyroxene and hornblende, and with secondary minerals such as chlorite. The same way, $\mathrm{CaCO}_{3}$ is associated with plagioclase and pyroxene minerals. Therefore, the dissolution of these minerals during the fluid/rock interaction process is responsible for the presence of elements in the water surface.

Among the three sampling groups of the Camaquã das Lavras Stream, approximately $86 \%$ of the samples from Group 1 were classified as intermediate hardness and only one sample (P14) was classified as soft. In the other two groups, the opposite occurs: $88 \%$ of the samples were classified as soft and only two samples show intermediate hardness (P17-Group 2; P2Group 3). In the Hilário Stream, the scenario repeats itself, only one sample (P33) shows intermediate hardness, while the other five samples of this stream were classified as soft.

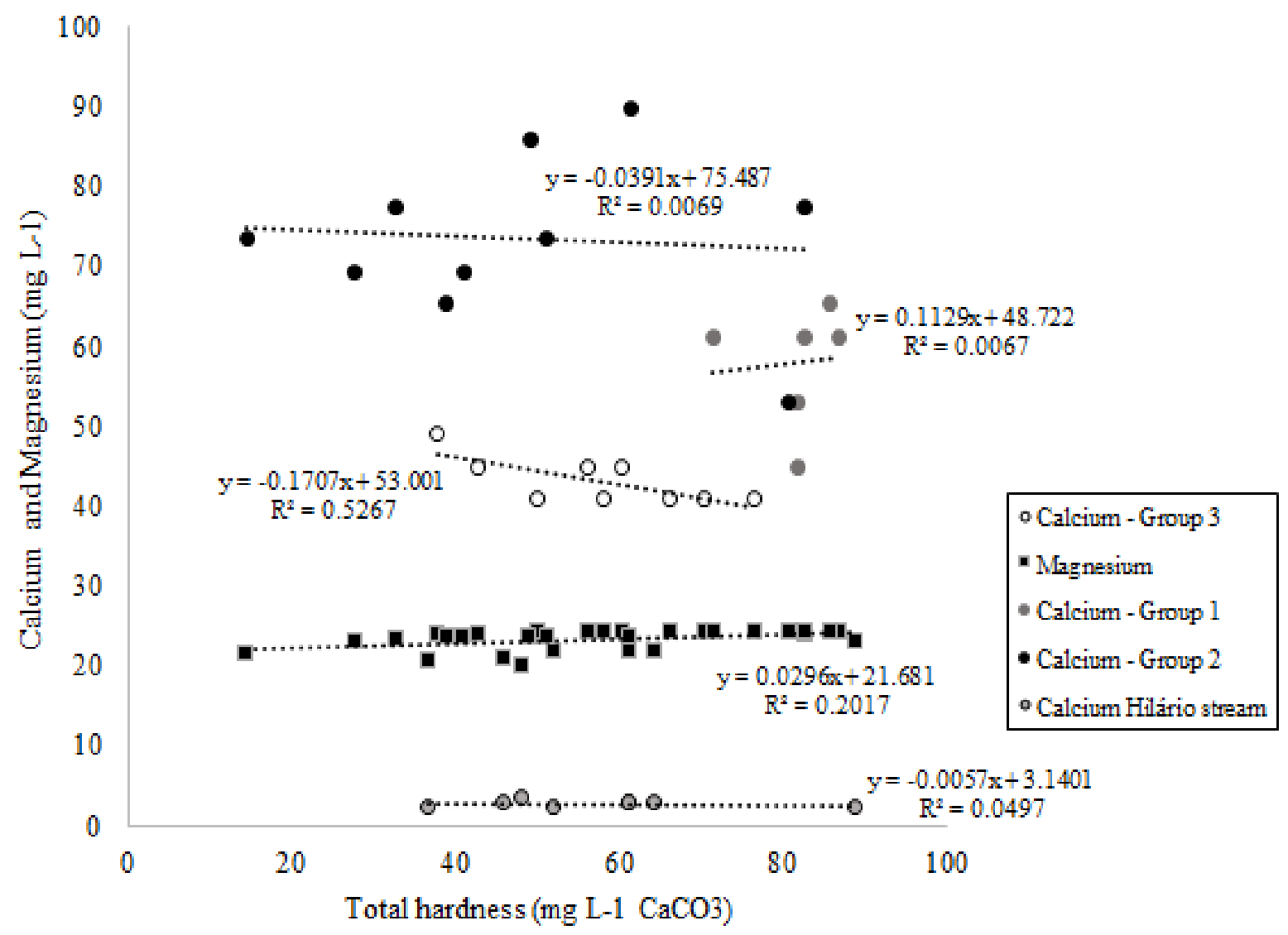

Figure 2. Relationship of calcium and magnesium with the total hardness. 


\subsection{EDRXF}

The EDXRF analysis showed that the concentrations of major and minor elements obtained (Table 2) are among the maximum values allowed for the elements contained in water as predicted by the Brasil-Ordinance $\mathrm{N}^{\circ} \cdot 357 / 2005$.

In terms of major elements, the silicon values obtained range from 0.13 (sample P25) to $0.65 \%$ (sample P31). In the Camaquã das Lavras Stream, there were varying amounts of silicon in the three groups. $\mathrm{SiO}_{2}(0.19$ and $0.13 \%)$ was detected in one sample of each group (samples P14 and P25). In Group 3, $\mathrm{SiO}_{2}$ content ranged from $0.17 \%$ (sample P1) to $0.26 \%$ (sample P4). In the Hilário Stream samples, the highest $\mathrm{SiO}_{2}$ content was observed, and values varied from 0.21 to $0.65 \%$. The $\mathrm{SiO}_{2}$ concentrations are associated with a filling of post-magmatic silica of andesites from the Hilário Formation.

The $\mathrm{Al}_{2} \mathrm{O}_{3}$ content detected varies according to the geographic layout of the samples. For example, the highest values are compatible with the water samples from the Hilário Stream, varying from 3.45 to $4.53 \%$. In the Camaquã das Lavras Stream, in Group 1, only two samples presented $\mathrm{Al}_{2} \mathrm{O}_{3}$ (samples $\mathrm{P} 10$ and $\mathrm{P} 11$; Table 2). In Group 2, $\mathrm{Al}_{2} \mathrm{O}_{3}$ was detected in nine samples from a total of ten samples, ranging from 0.43 to $0.84 \%$. In Group 3, only one sample (P6) presented $\mathrm{Al}_{2} \mathrm{O}_{3}(0.5 \%)$. The variation of $\mathrm{Al}_{2} \mathrm{O}_{3}$ values in the investigated samples was attributed to the presence of weathered clay minerals such as kaolinite.

To complement the chemical weathering ratio, the $\mathrm{K}_{2} \mathrm{O} / \mathrm{Al}_{2} \mathrm{O}_{3}$ elemental ratio was calculated using an indicator of the source rock composition (Cox et al., 1995). Cox et al. (1995) suggest a differentiated $\mathrm{K}_{2} \mathrm{O} / \mathrm{Al}_{2} \mathrm{O}_{3}$ ratio for clay minerals that varies from 0.0 to 0.3 and for feldspars from 0.3 to 0.9 . The $\mathrm{K}_{2} \mathrm{O} / \mathrm{Al}_{2} \mathrm{O}_{3}$ ratio ranged from 0.08 to 0.38 in the Camaqua das Lavras Stream samples and from 0.01 to 0.02 in the Hilário stream samples. These values suggest that clay minerals are the dominant weathered mineral in the investigated samples, with the exception of three water samples from the Camaquã das Lavras Stream, Group 2, samples $\mathrm{P} 17, \mathrm{P} 20$ and $\mathrm{P} 21$, the $\mathrm{K}_{2} \mathrm{O} / \mathrm{Al}_{2} \mathrm{O}_{3}$ ratios were $0.38,0.36$ and 0.37 , respectively. In this case, it is suggested that the dominant weathered mineral was feldspar.

The $\mathrm{K}_{2} \mathrm{O}$ was detected in all investigated water samples and the highest contents were obtained in the samples from Group 2 of the Camaquã das Lavras Stream, where they ranged from 0.14 to $0.20 \%$ (Table 2). In Groups 1 and 3, also from Camaquã das Lavras, the values ranged from 0.13 to $0.19 \%$ and from 0.01 to $0.06 \%$, respectively. Group 3 presents the lowest $\mathrm{K}_{2} \mathrm{O}$ values of the Camaquã das Lavras Stream samples as the water samples from the Hilário Stream. In this last one, the $\mathrm{K}_{2} \mathrm{O}$ values obtained ranged from 0.05 to $0.09 \%$. The $\mathrm{K}_{2} \mathrm{O}$ concentrations were attributed to the dissolution in a greater or lesser degree of white mica and alkali feldspar (Monzogranite facies and Perthite Granite), and clay minerals (andesite porphyritic from the Hilário Formation). These data are supported by petrography.

The $\mathrm{SiO}_{2}$ concentration ranged from 0.21 to $0.65 \%$ in the samples from the Hilário Stream. Groups 1 and 2 of the Camaquã das Lavras Stream show only two samples with $\mathrm{SiO}_{2}$ (P140.19\%; P25- 0.13\%, respectively). In Group 3, also from Camaquã das Lavras, the values ranged from 0.17 to $0.26 \%$. The $\mathrm{SiO}_{2}$ concentrations in the water samples are associated with a filling of post-magmatic silica of andesites (Hilário Formation).

$\mathrm{Cl}$ was detected in the water samples of the Hilário Stream, varying from 0.07 to $0.09 \%$. In water samples from Group 3 of the Camaquã das Lavras Stream, the $\mathrm{SiO}_{2}$ oscillates between 0.04 and $0.05 \%$. The $\mathrm{Cl}$ variation in Hilário and Camaquã das Lavras Streams is associated, probably, to two processes such as the weathering of white mica and chlorite (Lavras do Sul Intrusive Complex) and domestic waste. 
Table 2. Percentage of major and trace elements from the analyzed water.

\begin{tabular}{|c|c|c|c|c|c|c|c|c|c|c|}
\hline & & Sample & $\mathrm{Al}_{2} \mathrm{O}_{3}(\%)$ & $\mathrm{SiO}_{2}(\%)$ & $\mathrm{Cl}(\%)$ & $\mathrm{K}_{2} \mathrm{O}(\%)$ & $\operatorname{Rh}\left(m g L^{-1}\right)$ & $\left.\operatorname{Cd}(\operatorname{mg~L})^{-1}\right)$ & $\mathrm{Cu}\left(\mathrm{mg} \mathrm{L}^{-1}\right)$ & $\mathrm{K}_{2} \mathrm{O} / \mathrm{Al}_{2} \mathrm{O}_{3}$ \\
\hline \multirow{26}{*}{$\begin{array}{l}\text { Camaquã das } \\
\text { Lavras Stream }\end{array}$} & \multirow{9}{*}{ Group 3} & $\mathrm{P} 1$ & 0 & 0.17 & 0.05 & 0.02 & 21.3 & 0 & 0 & 0 \\
\hline & & $\mathrm{P} 2$ & 0 & 0.26 & 0.04 & 0.01 & 22.4 & 4.6 & 0 & 0 \\
\hline & & P3 & 0 & 0 & 0.04 & 0.02 & 21.6 & 0 & 0 & 0 \\
\hline & & $\mathrm{P} 4$ & 0 & 0.26 & 0.05 & 0.03 & 21.5 & 0 & 0 & 0 \\
\hline & & P5 & 0 & 0 & 0.04 & 0.03 & 21.6 & 0 & 0 & 0 \\
\hline & & P6 & 0.5 & 0.25 & 0.05 & 0.04 & 20.3 & 0 & 0 & 0.08 \\
\hline & & P7 & 0 & 0 & 0.04 & 0.06 & 22.1 & 4.8 & 0 & 0 \\
\hline & & P8 & 0 & 0 & 0.05 & 0.05 & 21.7 & 0 & 0 & 0 \\
\hline & & P9 & 0 & 0 & 0.05 & 0.02 & 21.1 & 4.4 & 0 & 0 \\
\hline & \multirow{7}{*}{ Group 1} & P 10 & 0.51 & 0 & 0 & 0.14 & 10.2 & 0 & 100 & 0.27 \\
\hline & & P 11 & 0.57 & 0 & 0 & 0.16 & 10.4 & 9.3 & 100 & 0.28 \\
\hline & & P 12 & 0 & 0 & 0 & 0.15 & 12 & 0 & 100 & 0 \\
\hline & & P 13 & 0 & 0 & 0 & 0.13 & 13.7 & 6.9 & 0 & 0 \\
\hline & & P 14 & 0 & 0.19 & 0 & 0.14 & 14.3 & 0 & 100 & 0 \\
\hline & & P 15 & 0 & 0 & 0 & 0.15 & 14.3 & 7.3 & 100 & 0 \\
\hline & & P 16 & 0 & 0 & 0 & 0.19 & 13.3 & 0 & 100 & 0 \\
\hline & \multirow{10}{*}{ Group 2} & P 17 & 0.45 & 0 & 0 & 0.17 & 13.8 & 7.4 & 100 & 0.38 \\
\hline & & P 18 & 0.61 & 0 & 0 & 0.17 & 13.5 & 7.4 & 100 & 0.28 \\
\hline & & P 19 & 0.58 & 0 & 0 & 0.14 & 12.8 & 6.9 & 100 & 0.24 \\
\hline & & P 20 & 0.45 & 0 & 0 & 0.16 & 13.1 & 0 & 100 & 0.36 \\
\hline & & P 21 & 0.43 & 0 & 0 & 0.16 & 12.4 & 7.6 & 100 & 0.37 \\
\hline & & P 22 & 0.5 & 0 & 0 & 0.19 & 12.2 & 8.4 & 100 & 0.38 \\
\hline & & P 23 & 0.84 & 0 & 0 & 0.19 & 10.8 & 0 & 0 & 0.23 \\
\hline & & P 24 & 0.48 & 0 & 0 & 0.17 & 11.1 & 7.4 & 100 & 0.35 \\
\hline & & P 25 & 0.71 & 0.13 & 0 & 0.19 & 11 & 8.3 & 100 & 0.27 \\
\hline & & P 26 & 0 & 0 & 0 & 0.2 & 11.4 & 0 & 100 & 0 \\
\hline \multirow{7}{*}{ Hilário Stream } & & P 27 & 3.45 & 0.21 & 0.07 & 0.05 & 0 & 0 & 100 & 0.01 \\
\hline & & P 28 & 4.53 & 0.29 & 0.07 & 0.05 & 0 & 0 & 0 & 0.01 \\
\hline & & P 29 & 3.45 & 0.57 & 0.07 & 0.07 & 0 & 0 & 0 & 0.02 \\
\hline & & P 30 & 4.37 & 0.34 & 0.07 & 0.09 & 0 & 0 & 0 & 0.02 \\
\hline & & P 31 & 3.45 & 0.65 & 0.07 & 0.08 & 0 & 0 & 0 & 0.02 \\
\hline & & P 32 & 3.45 & 0.54 & 0.09 & 0.08 & 0 & 0 & 0 & 0.02 \\
\hline & & P 33 & 3.45 & 0.25 & 0.09 & 0.07 & 4.3 & 0 & 0 & 0.02 \\
\hline
\end{tabular}

Note: $\mathrm{SiO}_{2}=0.10 ; \mathrm{Al}_{2} \mathrm{O}_{3}=0.1 ; \mathrm{K}_{2} \mathrm{O}=0.01 ; \mathrm{Cl}=0.01 ; \mathrm{Rh}=0.01 \mathrm{mg} \mathrm{L}^{-1} ; \mathrm{Cd}=0.01 \mathrm{mg} \mathrm{L}^{-1}$. 
Attention is called to the $\mathrm{Rh}$ and $\mathrm{Cd}$ contents detected in the samples of the Camaqua das Lavras Stream that are above that allowed by Ordinance $\mathrm{N}^{\circ} 357$ (Conama, 2005). In Group 1, the $\mathrm{Rh}$ content of the samples ranged from 10.2 to $14.3 \mathrm{mg} \mathrm{L}^{-1}$ (Table 2; Figure 3). In Group 2, the variation of the values was 10.8 to $13.8 \mathrm{~g} \mathrm{~L}^{-1}$ (Table 2; Figure 4). In Group 3 the highest Rh values for Camaquã das Lavras Stream are observed, which ranged from 20.3 to $22.4 \mathrm{mg} \mathrm{L}^{-1}$ (Table 2; Figure 3). $\mathrm{Rh}$ is an element of the platinum group, considerably resistant to weathering. Thus, its detection may be related to the weathering of soluble components from secondary minerals (like sericite and kaolinite) from the Lavras do Sul Intrusive Complex.

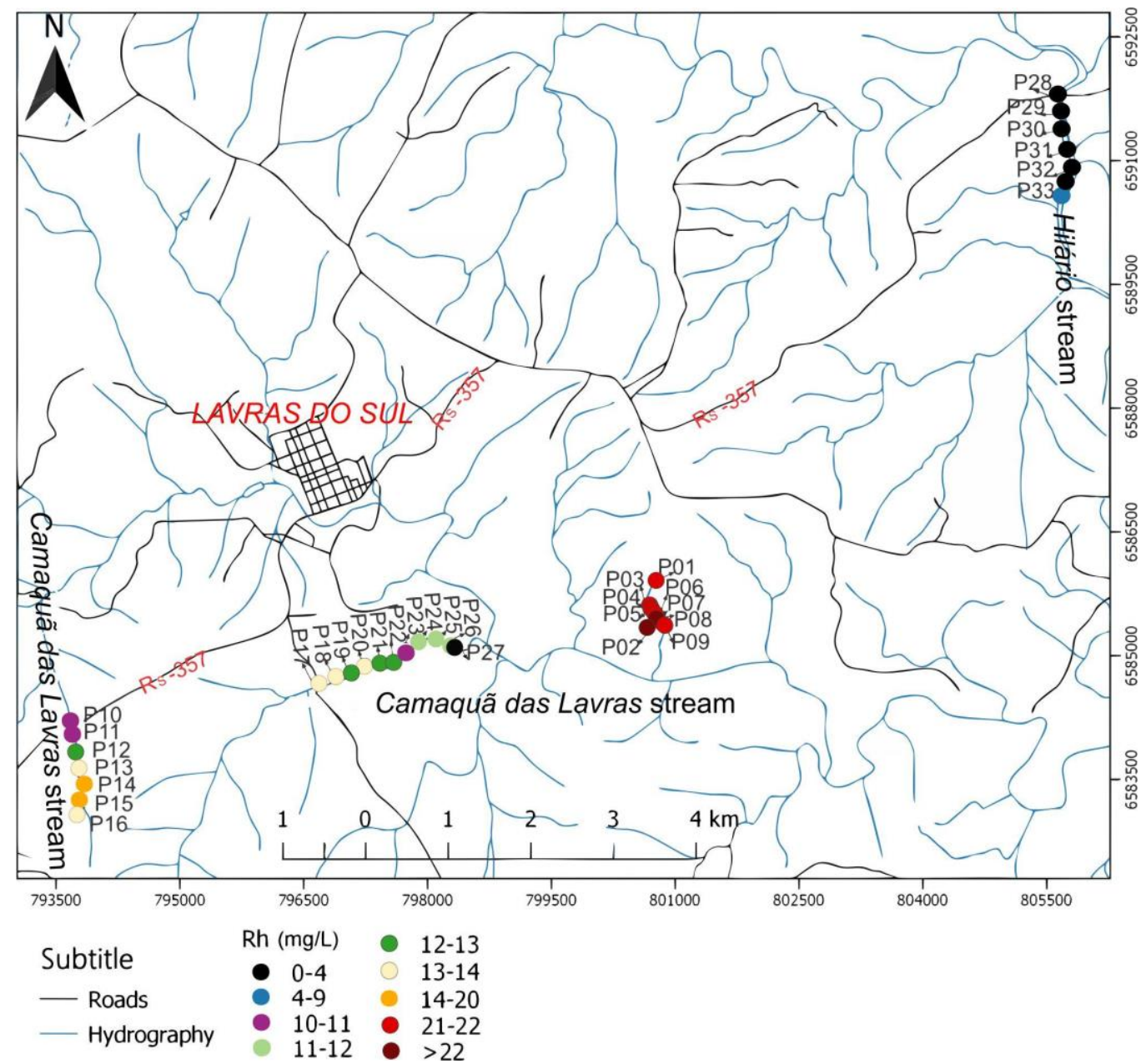

Figure 3. Rh concentrations in the studied area.

Cd was detected in most samples of Camaquã das Lavras Stream and in Group 1 and 3 only three samples presented $\mathrm{Cd}(\mathrm{P} 11, \mathrm{P} 13$, and $\mathrm{P} 15$; $\mathrm{P} 2, \mathrm{P} 7$, and $\mathrm{P} 9)$ ranging from 6.9 to 9.3 $\mathrm{mg} \mathrm{L}^{-1}$ and 4.4 to $4.8 \mathrm{mg} \mathrm{L}^{-1}$ (Table 2; Figure 4), respectively. In Group 2 of Camaquã das Lavras Stream, Cd contents ranged from 6.9 to $8.4 \mathrm{mg} \mathrm{L}^{-1}$ (Table 2; Figure 4) and P20, P23 and P26 samples was not detected Cd element. In the Hilário Stream, Rh was only detected in the sample P33 (4.3 $\mathrm{mg} \mathrm{L}^{-1}$; Table 2; Figure 4) and Cd element was not detected.

Some factors are related to $\mathrm{Cd}$ detection, for example, the use of phosphate fertilizers in the soil (1-170 mg. $\left.\mathrm{kg}^{-1}\right)$ (Tack, 2010) Cd is leached by rainwater and deposited in near water resources (Steffens et al., 2015). An anthropogenic source for Cd concentrations in the water streams is the improper disposal of equipment such as batteries (Martin and Griswold, 2009). In order to identify a mineral source for the $\mathrm{Cd}$ and $\mathrm{Rh}$ concentrations in the water streams, it can be added that both $\mathrm{Cd}$ and $\mathrm{Rh}$ behave similar to $\mathrm{Al}, \mathrm{K}, \mathrm{Ca}$, and $\mathrm{Mg}$. $\mathrm{Cd}$ and $\mathrm{Rh}$ can replace the elements in the aluminosilicates, even though they have a larger atomic weight they can be 
adsorbed on clay minerals, kaolinite and smectite type (Caldarone et al., 1994; Guerra et al., 2008). However, in Figure 5 it may be observed that the highest Cd concentrations are close to or in the direction of the flow of the stream from the Lavras do Sul urban center, which suggests an anthropic influence.

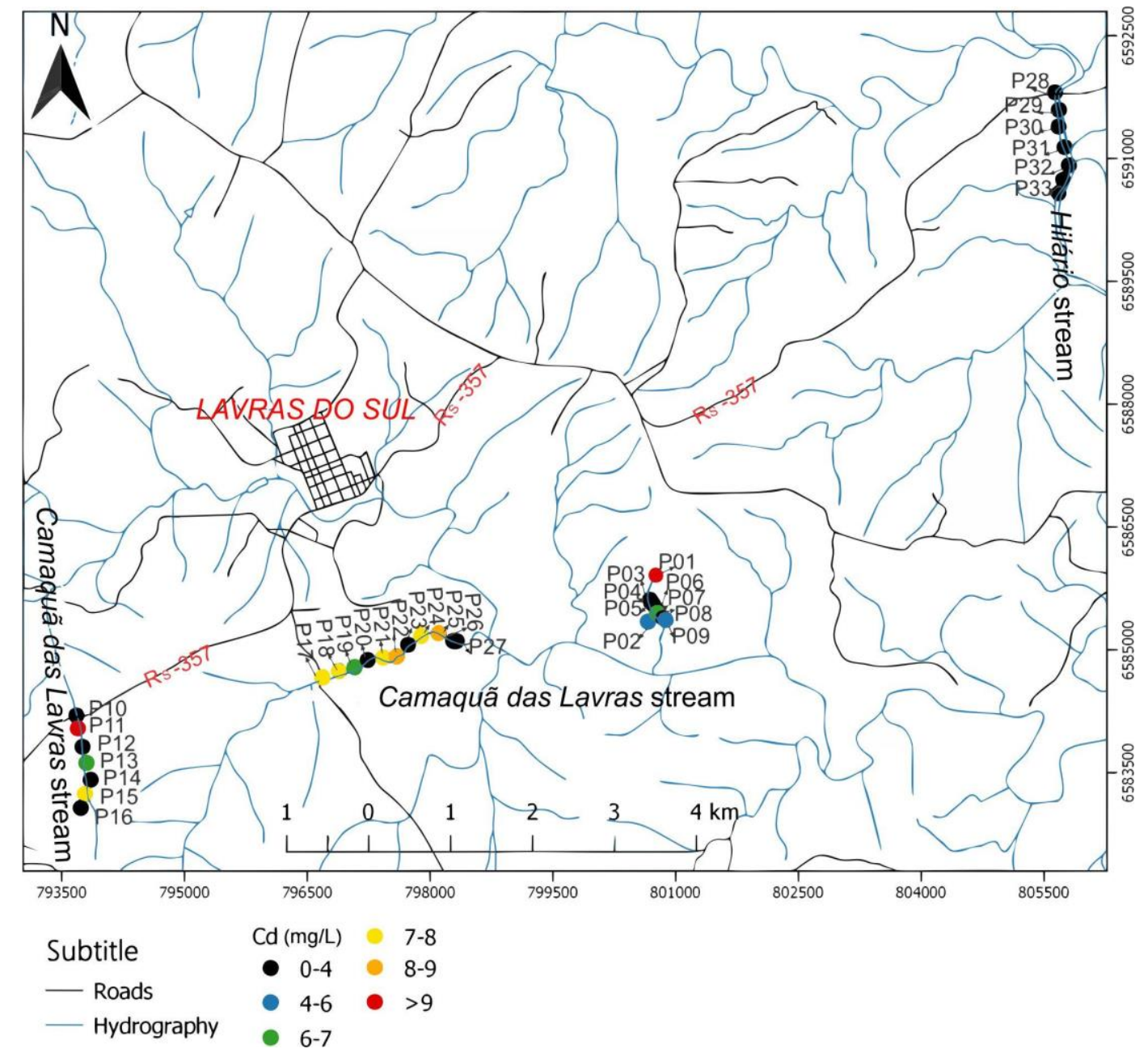

Figure 4. Cd concentrations in the studied area.

In terms of trace elements, $\mathrm{Cu}$ was notably detected in the samples of Groups 1 and 2 of the Camaquã das Lavras Stream, possibly associated with the mineralization of weathered sulfides (Pestana and Formoso, 2003; Rieuwerts et al., 2006).

\subsection{Statistical Analysis}

In order to investigate the positive or negative correlations between the traces and larger elements of the water samples of the investigated streams, in terms of descriptive statistical correlation (Table 3), the Pearson's correlation matrix was applied (Mukaka, 2012). In this way, it was possible to relate the elements to the lithology of the studied area, enabling the knowledge of which elements are in fact, the source material and which elements are present due to human intervention.

Using the Pearson correlation matrix, it is possible to summarize the relationship between the two variables. The most common way to present and analyze bivariate data sets is through the $\mathrm{X}$ and $\mathrm{Y}$ axes. This correlation measures the similarity between two different variables. The coefficient varies between -1 to +1 . The variables that present $r>0.7$ are considered strongly correlated, while $r>0.5-0.7$ shows moderate correlation at a significant level $(p \leq 0.05$ with a confidence level of 95\% (Table 3 and 4; Mukaka, 2012). 
The Pearson correlation matrix was constructed for the water samples of the Camaquã das Lavras Stream (Table 3), where it shows significant positive correlations between $\mathrm{Cl}-\mathrm{Rh}$; and $\mathrm{K}_{2} \mathrm{O}$-alkalinity, $\mathrm{Cu}$. Moderate positive correlations were observed among the following parameters: $\mathrm{Al}_{2} \mathrm{O}_{3}-\mathrm{K}_{2} \mathrm{O}$, alkalinity, EC; $\mathrm{K}_{2} \mathrm{O}-\mathrm{Ca}$; alkalinity-Ca; and Hardness-Mg. Significant negative correlations are observed between $\mathrm{Cl}-\mathrm{K}_{2} \mathrm{O}$, alkalinity, $\mathrm{Cu}$; and $\mathrm{Rh}-\mathrm{K}_{2} \mathrm{O}$, alkalinity, $\mathrm{Cu}$; and moderate negative correlations on $\mathrm{Al}_{2} \mathrm{O}_{3}-\mathrm{Rh}$; Hardness- $\mathrm{pH} ; \mathrm{Ca}-\mathrm{Cl}, \mathrm{Rh}$. In the Camaquã das Lavras samples, the $\mathrm{Cd}$ shows weak positive correlations among $\mathrm{Al}_{2} \mathrm{O}_{3}$, alkalinity, $\mathrm{EC}$, $\mathrm{K}_{2} \mathrm{O}$, Ca, and $\mathrm{Rh}$, and the negative correlations are also weak between $\mathrm{Cl}$ and $\mathrm{Rh}$.

The main ion exchanges can be related to the correlation coefficients found within the same order. Thus, it is possible that the simultaneous increase or decrease in cations is the result, mainly, of ion-exchange effects in the mineral assemblage of the geological substrate in the investigated waters. Cd is usually associated with zinc ores, such as sphalerite ( $\mathrm{ZnS}$; Rimstidt et al., 1994). It is a chemical element extensively used in the industry to build materials such as cement and phosphate fertilizers. Thus, the $\mathrm{Cd}$ presence in the water samples can be associated to the fact that Lavras do Sul region has a strong mining activity of copper and lead, and agricultural activities, that make use of large amounts of phosphate fertilizers for soil correction.

Table 3. Pearson correlation matrix among the data obtained for the water samples from the Camaquã das Lavras Stream.

\begin{tabular}{cccccccccccccc}
\hline Variable & $\mathrm{Mg}$ & $\mathrm{Al}_{2} \mathrm{O}_{3}$ & $\mathrm{SiO}_{2}$ & $\mathrm{Cl}$ & $\mathrm{K}_{2} \mathrm{O}$ & Alkalinity & $\mathrm{EC}$ & $\mathrm{Ca}$ & Hardness & $\mathrm{Ph}$ & $\mathrm{Rh}$ & $\mathrm{Cd}$ & $\mathrm{Cu}$ \\
\hline $\mathrm{Mg}$ & $\mathbf{1}$ & -0.15 & 0.23 & 0.34 & -0.43 & -0.37 & -0.19 & 0.22 & $\mathbf{0 . 5 5}$ & -0.14 & 0.34 & -0.04 & -0.37 \\
$\mathrm{Al}_{2} \mathrm{O}_{3}$ & -0.15 & $\mathbf{1}$ & -0.15 & -0.49 & $\mathbf{0 . 5 5}$ & $\mathbf{0 . 5 0}$ & $\mathbf{0 . 6 8}$ & 0.48 & -0.36 & 0.24 & $\mathbf{- 0 . 6 1}$ & 0.40 & 0.40 \\
$\mathrm{SiO}_{2}$ & 0.23 & -0.15 & $\mathbf{1}$ & 0.47 & -0.47 & -0.43 & -0.13 & -0.24 & 0.06 & -0.06 & 0.44 & -0.24 & -0.35 \\
$\mathrm{Cl}$ & 0.34 & -0.49 & 0.47 & $\mathbf{1}$ & $\mathbf{- 0 . 9 5}$ & $\mathbf{- 0 . 9 8}$ & -0.40 & $\mathbf{- 0 . 5 8}$ & -0.05 & 0.31 & $\mathbf{0 . 9 5}$ & -0.40 & $\mathbf{- 0 . 8 4}$ \\
$\mathrm{K}_{2} \mathrm{O}$ & -0.43 & $\mathbf{0 . 5 5}$ & -0.47 & $\mathbf{- 0 . 9 5}$ & $\mathbf{1}$ & $\mathbf{0 . 9 6}$ & 0.37 & $\mathbf{0 . 5 3}$ & -0.04 & -0.20 & $\mathbf{- 0 . 9 5}$ & 0.36 & $\mathbf{0 . 8 2}$ \\
$\mathrm{Alkalinity}$ & -0.37 & $\mathbf{0 . 5 0}$ & -0.43 & $\mathbf{- 0 . 9 8}$ & $\mathbf{0 . 9 6}$ & $\mathbf{1}$ & 0.39 & $\mathbf{0 . 5 8}$ & 0.00 & -0.27 & $\mathbf{- 0 . 9 4}$ & 0.43 & $\mathbf{0 . 8 3}$ \\
$\mathrm{EC}$ & -0.19 & $\mathbf{0 . 6 8}$ & -0.13 & -0.40 & 0.37 & 0.39 & $\mathbf{1}$ & 0.08 & -0.22 & 0.18 & -0.48 & 0.31 & 0.33 \\
$\mathrm{Ca}$ & 0.22 & 0.48 & -0.24 & $\mathbf{- 0 . 5 8}$ & $\mathbf{0 . 5 3}$ & $\mathbf{0 . 5 8}$ & 0.08 & $\mathbf{1}$ & -0.03 & -0.15 & $\mathbf{- 0 . 5 3}$ & 0.43 & 0.49 \\
$\mathrm{Hardness}$ & $\mathbf{0 . 5 5}$ & -0.36 & 0.06 & -0.05 & -0.04 & 0.00 & -0.22 & -0.03 & $\mathbf{1}$ & $\mathbf{- 0 . 6 3}$ & -0.05 & -0.08 & -0.02 \\
$\mathrm{pH}$ & -0.14 & 0.24 & -0.06 & 0.31 & -0.20 & -0.27 & 0.18 & -0.15 & $\mathbf{- 0 . 6 3}$ & $\mathbf{1}$ & 0.23 & 0.02 & -0.33 \\
$\mathrm{Rh}$ & 0.34 & $\mathbf{- 0 . 6 1}$ & 0.44 & $\mathbf{0 . 9 5}$ & $\mathbf{- 0 . 9 5}$ & $\mathbf{- 0 . 9 4}$ & -0.48 & $\mathbf{- 0 . 5 3}$ & -0.05 & 0.23 & $\mathbf{1}$ & -0.36 & $\mathbf{- 0 . 8 2}$ \\
$\mathrm{Cd}$ & -0.04 & 0.40 & -0.24 & -0.40 & 0.36 & 0.43 & 0.31 & 0.43 & -0.08 & 0.02 & -0.36 & $\mathbf{1}$ & 0.38 \\
$\mathrm{Cu}$ & -0.37 & 0.40 & -0.35 & $\mathbf{- 0 . 8 4}$ & $\mathbf{0 . 8 2}$ & $\mathbf{0 . 8 3}$ & 0.33 & 0.49 & -0.02 & -0.33 & $\mathbf{- 0 . 8 2}$ & 0.38 & $\mathbf{1}$ \\
\hline
\end{tabular}

The Pearson correlation matrix was also built for the water samples of the Hilário Stream (Table 4). It shows that there is a significant positive correlation among the following parameters: Hardness- $\mathrm{Mg}, \mathrm{Rh} ; \mathrm{SiO}_{2}-\mathrm{Ca}$; $\mathrm{EC}-\mathrm{Cu}$; and $\mathrm{Rh}-\mathrm{Mg}$. There is a moderate positive correlation with $\mathrm{SiO}_{2}-\mathrm{K}_{2} \mathrm{O}$; and $\mathrm{Cl}-\mathrm{Rh}$. The correlation analysis for the Hilário Stream samples also reveals a significant negative correlation between only $\mathrm{SiO}_{2}-\mathrm{Hardness}$. Moderate negative correlations are observed with $\mathrm{Mg}$-Hardness, $\mathrm{Cu}$; $\mathrm{SiO}_{2}-\mathrm{Cu}$; $\mathrm{K}_{2} \mathrm{O}$-alkalinity, Hardness, $\mathrm{Cu}$; EC$\mathrm{Mg}, \mathrm{K}_{2} \mathrm{O}, \mathrm{Ca}$, Hardness; pH-Ca; and Hardness- $\mathrm{Cu}$.

Table 4. Pearson correlation matrix among the data obtained for the water samples from the Hilário Stream.

\begin{tabular}{ccccccccccccc}
\hline Variable & $\mathrm{Mg}$ & $\mathrm{Al}_{2} \mathrm{O}_{3}$ & $\mathrm{SiO}_{2}$ & $\mathrm{Cl}$ & $\mathrm{K}_{2} \mathrm{O}$ & Alkalinity & $\mathrm{EC}$ & $\mathrm{Ca}$ & Hardness & $\mathrm{pH}$ & $\mathrm{Rh}$ & $\mathrm{Cu}$ \\
\hline $\mathrm{Mg}$ & $\mathbf{1}$ & 0.10 & -0.04 & 0.21 & 0.22 & -0.31 & $\mathbf{- 0 . 6 1}$ & -0.12 & $\mathbf{0 . 9 7}$ & -0.35 & $\mathbf{0 . 7 3}$ & $\mathbf{- 0 . 6 2}$ \\
$\mathrm{Al}_{2} \mathrm{O}_{3}$ & 0.1 & $\mathbf{1}$ & -0.36 & -0.40 & -0.07 & -0.19 & 0.05 & -0.04 & -0.07 & -0.14 & -0.26 & -0.26 \\
$\mathrm{SiO}_{2}$ & -0.04 & -0.36 & $\mathbf{1}$ & -0.05 & $\mathbf{0 . 5 4}$ & 0.06 & $\mathbf{- 0 . 7 1}$ & $\mathbf{0 . 7 5}$ & -0.01 & -0.06 & -0.39 & $\mathbf{- 0 . 5 0}$ \\
$\mathrm{Cl}$ & 0.21 & -0.40 & -0.05 & $\mathbf{1}$ & 0.22 & -0.24 & -0.20 & -0.09 & 0.36 & -0.01 & $\mathbf{0 . 6 5}$ & -0.26 \\
$\mathrm{~K} 2 \mathrm{O}$ & 0.22 & -0.07 & $\mathbf{0 . 5 4}$ & 0.22 & $\mathbf{1}$ & $\mathbf{- 0 . 5 0}$ & $\mathbf{- 0 . 5 4}$ & 0.00 & 0.12 & 0.49 & 0.00 & $\mathbf{- 0 . 5 8}$ \\
$\mathrm{Alkalinity}$ & -0.31 & -0.19 & 0.06 & -0.24 & $\mathbf{- 0 . 5 0}$ & $\mathbf{1}$ & 0.10 & 0.27 & -0.20 & 0.00 & -0.24 & 0.43 \\
Conductivity & $\mathbf{- 0 . 6}$ & 0.05 & $\mathbf{- 0 . 7 1}$ & -0.20 & $\mathbf{- 0 . 5 4}$ & 0.10 & $\mathbf{1}$ & $\mathbf{- 0 . 6 0}$ & $\mathbf{- 0 . 6 2}$ & 0.34 & -0.15 & $\mathbf{0 . 9 0}$ \\
$\mathrm{Ca}$ & -0.12 & -0.04 & $\mathbf{0 . 7 5}$ & -0.09 & 0.00 & 0.27 & $\mathbf{- 0 . 6 0}$ & $\mathbf{1}$ & -0.03 & $\mathbf{- 0 . 5 7}$ & -0.47 & -0.47 \\
$\mathrm{Hardness}$ & $\mathbf{0 . 9 7}$ & -0.07 & -0.01 & 0.36 & 0.12 & -0.20 & $\mathbf{- 0 . 6 2}$ & -0.03 & $\mathbf{1}$ & -0.44 & $\mathbf{0 . 8 1}$ & $\mathbf{- 0 . 5 8}$ \\
$\mathrm{pH}$ & -0.35 & -0.14 & -0.06 & -0.01 & 0.49 & 0.00 & 0.34 & $\mathbf{- 0 . 5 7}$ & -0.44 & $\mathbf{1}$ & -0.14 & 0.38 \\
$\mathrm{Rh}$ & $\mathbf{0 . 7 3}$ & -0.26 & -0.39 & $\mathbf{0 . 6 5}$ & 0.00 & -0.24 & -0.15 & -0.47 & $\mathbf{0 . 8 1}$ & -0.14 & $\mathbf{1}$ & -0.17 \\
$\mathrm{Cu}$ & $\mathbf{- 0 . 6 2}$ & -0.26 & $\mathbf{- 0 . 5 0}$ & -0.26 & $\mathbf{- 0 . 5 8}$ & 0.43 & $\mathbf{0 . 9 0}$ & -0.47 & $\mathbf{- 0 . 5 8}$ & 0.38 & -0.17 & $\mathbf{1}$ \\
\hline
\end{tabular}


For the chemical analysis of water properties, Principal Component Analysis (PCA) was applied, based on the correlation matrix between the components and the standardized variables. In the same way, as in Pearson correlation matrix, the data of water samples investigated for each stream were interpreted separately.

Therefore, in the Camaquã das Lavras Stream, 10 PCs represent $100 \%$ of the variance of the obtained results (Table 5). The first three PCs are $>1$, representing $77.45 \%$ of the variance (Table 5; Figure 5). For the water samples of the Hilário Stream, 6 PCs represent $100 \%$ of the variance in the results obtained (Table 5). The first four PCs presented values higher than 1, representing $87.57 \%$ of the variance (Table 5; Figure 5). The first and second principal components (PC1 and PC2) of the samples investigated from Camaquã das Lavras Stream are the result of the linear combination of 15 variables studied, and both PCs explained $43.23 \%$ and $21.62 \%$ of the variance, respectively (Table 5). On the other hand, PC1 and PC2 of the samples investigated from Hilário Stream are the results of the linear combination of 12 variables studied, and both PCs explained $32.35 \%$ and $22.43 \%$ of the variance, respectively (Table 5).

Table 5. Eigenvalues of correlation matrix and related statistics of the water from Camaquã das Lavras and Hilário Stream.

\begin{tabular}{|c|c|c|c|c|c|c|c|c|c|}
\hline $\begin{array}{c}\text { PCs } \\
\text { (Camaquã } \\
\text { das Lavras } \\
\text { Stream) }\end{array}$ & Eigenvalue & $\begin{array}{c}\text { Total } \\
\text { variance } \\
\%\end{array}$ & $\begin{array}{l}\text { Cumulative } \\
\text { Eigenvalue }\end{array}$ & $\begin{array}{c}\text { Cumulative } \\
\%\end{array}$ & $\begin{array}{c}\text { PCs } \\
\text { (Hilário } \\
\text { Stream) }\end{array}$ & Eigenvalue & $\begin{array}{c}\% \text { Total } \\
\text { Variance }\end{array}$ & $\begin{array}{l}\text { Cumulative } \\
\text { Eigenvalue }\end{array}$ & $\begin{array}{c}\text { Cumulative } \\
\%\end{array}$ \\
\hline 1 & 4.323426 & 43.23426 & 4.32343 & 43.2343 & 1 & 3.234724 & 32.34724 & 3.23472 & 32.3472 \\
\hline 2 & 2.161721 & 21.61721 & 6.48515 & 64.8515 & 2 & 2.242775 & 22.42775 & 5.47750 & 54.7750 \\
\hline 3 & 1.260404 & 12.60404 & 7.74555 & 77.4555 & 3 & 1.947951 & 19.47951 & 7.42545 & 74.2545 \\
\hline 4 & 0.914707 & 9.14707 & 8.66026 & 86.6026 & 4 & 1.331926 & 13.31926 & 8.75738 & 87.5738 \\
\hline 5 & 0.732895 & 7.32895 & 9.39315 & 93.9315 & 5 & 0.788816 & 7.88816 & 9.54619 & 95.4619 \\
\hline 6 & 0.288557 & 2.88557 & 9.68171 & 96.8171 & 6 & 0.453809 & 4.53809 & 10.00000 & 100.0000 \\
\hline 7 & 0.204632 & 2.04632 & 9.88634 & 98.8634 & & & & & \\
\hline 8 & 0.062680 & 0.62680 & 9.94902 & 99.4902 & & & & & \\
\hline 9 & 0.032276 & 0.32276 & 9.98130 & 99.8130 & & & & & \\
\hline 10 & 0.018701 & 0.18701 & 10.00000 & 100.0000 & & & & & \\
\hline
\end{tabular}

The PCA also produces eigenvectors, known as coefficients or charges of principal components (Figure 5). It describes the relative importance of a component, for example, a chemical element and its variability between a data group. Eigenvectors automatically calculate the score for each PC. The values of the element loads determine the score of a sampling point. Thus, the grouping of high-load elements provides high scores, and the grouping of lowpayload elements provides low scores. The number of eigenvectors calculated will be equal to the number of variables used, which in this study is the number of chemical elements and parameters analyzed (Reimann et al., 2008).

For PC1 (variation of $43.23 \%$ ) of the elements and parameters of Camaquã das Lavras Stream, high scores are commensurate to high load elements (>0.2), for example, $\mathrm{Mg}, \mathrm{SiO}_{2}$, $\mathrm{Cl}$ and $\mathrm{Rh}$ (Figure 5A). The lowest scores are equivalent to the lowest rates $(<0.19)$, such as $\mathrm{pH}$ and Hardness. High scores for PC2 are related to strong positive loads $(>0.2)$ for $\mathrm{Ca}$, alkalinity and $\mathrm{Cu}$, with low rates related to $\mathrm{Cd}$ and $\mathrm{K}_{2} \mathrm{O}$ (Fig. 5A).

In the Hilário Stream, the highest scores of $\mathrm{PC} 1$ with a variation of $32.35 \%$ are represented by $\mathrm{pH}, \mathrm{EC}, \mathrm{Cu}$ and alkalinity (Figure 5B), being the lowest rate equivalent to $\mathrm{Al}_{2} \mathrm{O}_{3}$. For $\mathrm{PC} 2$, the highest scores are equivalent hardness, $\mathrm{Mg}, \mathrm{Cl}$ and $\mathrm{Rh}$, in that only $\mathrm{K}_{2} \mathrm{O}$ shows numbers lower than 0.19 . 


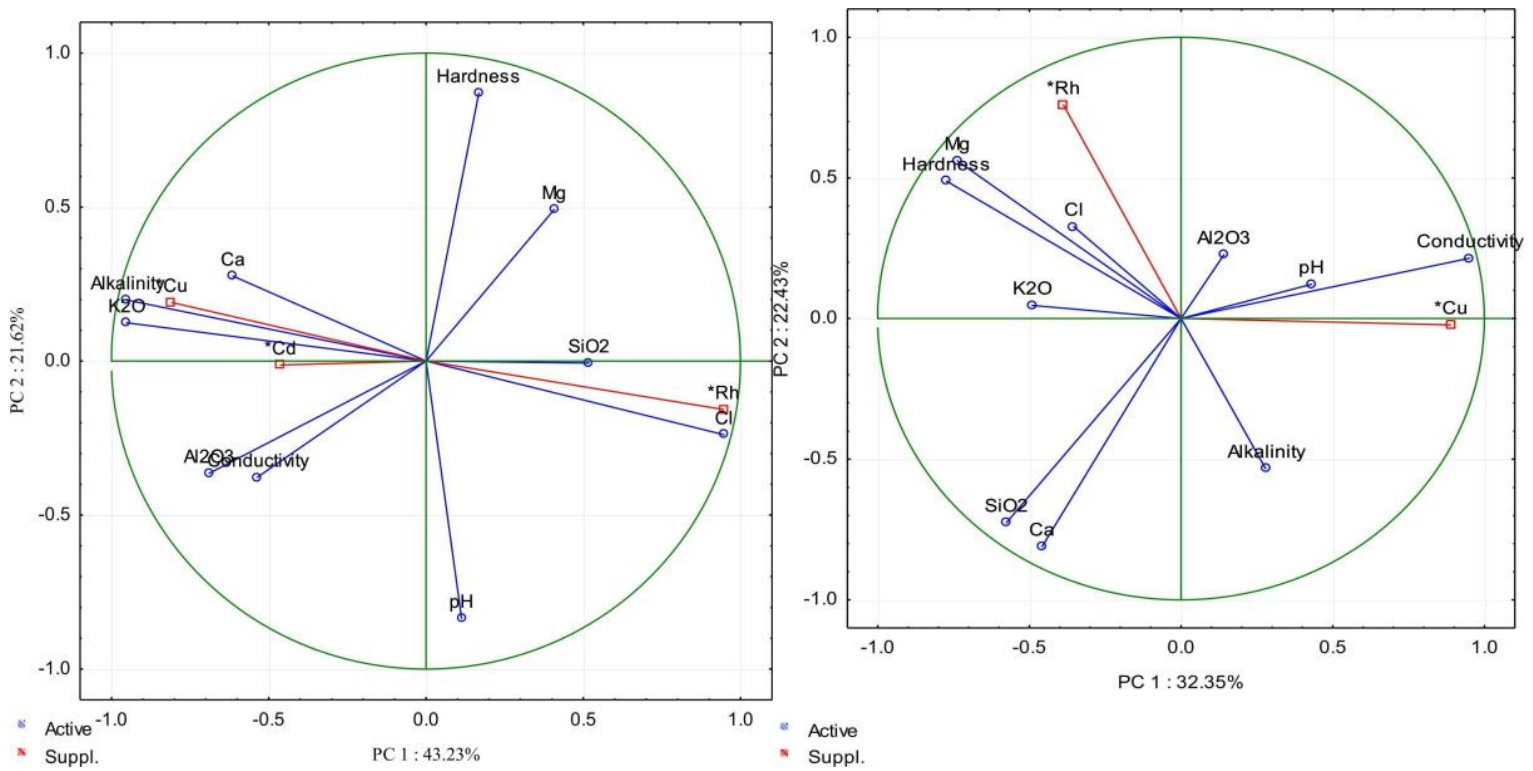

Figure 5. (A) Projection of the variables on the factor-plane (PC1 and PC2) from eigenvectors in Camaquã das Lavras Stream. (B) Projection of the variables on the factor-plane (PC1 and PC2) from eigenvectors in Hilário Stream.

\section{CONCLUSIONS}

The data provide new understanding of the chemical composition of the Camaqua das Lavras and Hilário streamS, in Lavras do Sul municipality. Thus, it is observed that:

(1) The $\mathrm{pH}$ values indicate acidic to near neutral waters, with indices ranging from 5.47 to 6.72 ;

(2) The measured the total alkalinity values varied geographically, with enrichment of hydroxides and increasing bicarbonates in the samples from Group 3 (Camaquã das Lavras Stream) towards the samples of the Hilário and from Group 1 to the samples from Group 2 samples of the Camaquã das Lavras Stream.

(3) The plagioclase, chlorite, amphibole and pyroxene weathering suggest a direct influence of the granitoids from Lavras do Sul Intrusive Complex and the volcanic rocks from Hilário Formation (andesite). After weathering, $\mathrm{Ca}$ and $\mathrm{Mg}$ ions are released into nearby water resources. These data corroborate with the soft, intermediate and temporary hardness of the water samples in the studied area;

(4) The EDXRF data of the $\mathrm{K}_{2} \mathrm{O} / \mathrm{Al}_{2} \mathrm{O}_{3}$ ratio show that clay minerals are the dominant weathered mineral in Camaquã das Lavras and Hilário Streams, resulting from the alkali feldspar weathering;

(5) The $\mathrm{SiO}_{2}$ quantities found in water samples are associated with a filling of postmagmatic silica in andesites fromthe Hilário Formation. The $\mathrm{Al}_{2} \mathrm{O}_{3}$ values were attributed to the weathering of clay, such as kaolinite, with the highest values obtained in the Hilário Stream. The $\mathrm{K}_{2} \mathrm{O}$ suggests the dissolution of white mica, alkali feldspar (Monzogranite and Perthite Granite), and clay minerals (Hilário Formation). The greatest $\mathrm{K}_{2} \mathrm{O}$ contributions were obtained in the water samples of the Camaquã das Lavras Stream;

(6) $\mathrm{Cd}$ and $\mathrm{Rh}$ elements were detected in the Camaquã das Lavras Stream, above the values permitted by the Ordinance $N^{\text {o. }}$ 2914/2011 (Brasil, 2011).

All the geochemical and statistical analyses carried out the Camaquã das Lavras and Hilário Streams conform with a natural influence of the rock substrate type in these waters, except for the $\mathrm{Cd}$ that may also be related to anthropic influence. The results point to the need for further studies to better characterize the possible $\mathrm{Cd}$ sources in the local waters and an association with cases of infectious and other diseases. Removal of heavy metals is an important 
step towards safe potable water. We suggest some methods for removing $\mathrm{Cd}$, such as adsorption, chemical precipitation, physical separation, ion exchange, membrane filtration, membrane distillation and hybrid methods.

\section{ACKNOWLEDGEMENTS}

The data presented in this study were obtained under Project Recognition of Prospective Indicators of Mineral Deposits in the Center-South Region of Rio Grande do Sul $\left(\mathrm{N}^{\mathrm{o}}\right.$ 03.016.16). We also acknowledge the financial support at Research Support Foundation of the State of Rio Grande do Sul (FAPERGS), Academic Development Program (UNIPAMPA) and National Council for Scientific and Technological (CNPq).

\section{REFERENCES}

AGÊNCIA NACIONAL DE VIGILÂNCIA SANITÁRIA (Brasil). Portaria n. 1469, de 29 de dezembro de 2000. Estabelece os procedimentos e responsabilidades relativos ao controle e vigilância da qualidade da água para consumo humano e seu padrão de potabilidade, e dá outras providências. Diário Oficial [da] União: seção 1, Brasília, DF, p. 19, 02 jan. 2001.

APHA; AWWA; WEF. Standard Methods for the Examination of Water and Wastewater. 21. ed. Washington, 2005.

ABNT. NBR 12621: águas - determinação da dureza total - Método titulométrico do EDTANa. Rio de Janeiro, 1992.

BAKALOWICZ, M. Water Geochemistry: Water Quality and Dynamics. Groundwater Ecology, p. 97-127, 1994. https://dx.doi.org/10.1016/B978-0-08-050762-0.50011-5

BATISTA, M. J. A. F. Comportamento de elementos químicos no sistema rocha-solosedimento-planta na área mineira de Neves do Corvo: Implicações ambientais. 2003. 37p. Tese (Doutorado em Geociências) - Universidade de Aveiro, Aveiro, 2003.

BONA, I. A. T.; SARKIS, J. S.; SALVADOR, V. L. R. Análise arqueométrica de cerâmica Tupiguarani da região central do Estado do Rio Grande do Sul, Brasil, usando fluorescência de raios X por dispersão de energia (EDXRF). Química Nova, v. 30, p. $785,2007$.

BRASIL. Ministério da Saúde. Portaria n. 2.914, de 12 de dezembro de 2011. Dispõe sobre os procedimentos de controle e de vigilância da qualidade da água para consumo humano e seu padrão de potabilidade. Diário Oficial [da] União: seção 1, Brasília, DF, p. 39, 14 de dez. de 2011.

BRASIL. Ministério da Saúde. Portaria GM/MS nº 36, de 19 de janeiro de 1990. Aprova normas e o padrão de Potabilidade da Água destinada ao Consumo Humano, a serem observadas em todo o território nacional. Diário Oficial [da] União: seção 1, Brasília, DF, 23 de jan. 1990.

CALDARONE, M. A.; GRUBER, K. A.; BURG, R. G. High-reactivity metakaolin: a new generation mineral admixture. Concrete International, v. 16, n. 11, p. 37-40, 1994.

CETESB. Valores orientadores para solos e águas subterrâneas. 2016. Available at: http://www.cetesb.sp.gov.br/

CHEREMISINOFF, N. P. Principles of Geology. Groundwater Remediation and Treatment Technologies, p. 1-37, 1997. 
CONAMA (Brasil). Resolução no 357 de 17 de março de 2005. Dispõe sobre a classificação dos corpos de água e diretrizes ambientais para o seu enquadramento, bem como estabelece as condições e padrões de lançamento de efluentes, e dá outras providências. Diário Oficial [da] União: seção 1, Brasília, DF, n. 053, p. 58-63, 18 mar. 2005.

CONSELHO DE RECURSOS HÍDRICOS (RS). Resolução n. 206, de 14 de setembro de 2016. Aprova o Enquadramento das águas superficiais da Bacia Hidrográfica do Rio Camaquã. Diário Oficial, Porto Alegre, n. 228, 01 dez. 2016.

COX, R.; LOWE, D. R.; CULLERS, R. L. The influence of sediment recycling and basement composition on evolution of mudrock chemistry in the south-western United States. Geochim Cosmochim Acta, v. 59, p. 2919-2940, 1995. https://doi.org/10.1016/00167037(95)00185-9

DE LIZ, J. D.; NARDI, L. V. S.; DE LIMA, E. F.; JARVIS, K. The trace-element record in zircon from the Lavras do Sul shoshonitic association, Southernmost Brazil. Canadian Mineralogist, v. 47, p. 833-846, 2009. https://doi.org/10.3749/canmin.47.4.833

FUNASA. Manual prático de análise de água 2. 2006. Available at: http://www.funasa.gov.br/site. Access: Nov. 2019

GASTAL, M. C.; FERREIRA, F. J. F.; CUNHA, J. U.; ESMERIS, C.; KOESTER, E.; RAPOSO, M. I. B.; ROSSETT, M. M. M. Lavras granite emplacement and gold mineralization during the development of the post-collisional volcano plutonic center, west of the Sul-Rio grandence Shield: Geophysical and structural data. Brazilian Journal $\begin{array}{llllllll}\text { of Geology, } & \text { n. } & 45, & \text { v. } & 2, & \text { p. } & 217-241,\end{array}$ https://dx.doi.org/10.1590/23174889201500020004

GOMES, C. H.; SCHMIDT, A. M.; DESSART, R. L.; CASANOVA, G. P. Geochemical analyses of water and public health of the Mangueirão and Salso Streams in Caçapava do Sul, RS, Brazil. Revista Ambiente \& Água, n. 12, v. 5, p. 760-773, 2017. http://dx.doi.org/10.4136/ambi-agua.2006

GOMES, C. H.; ALMEIDA, D. P. M.; SPERANDIO, D. G. Sediment Geochemistry at the Confluence of Baixo Jacuí and Vacacaí-Mirim Hydrographic Basins, Caçapava do SulRS: Implications for Provenance and Chemical Weathering. Anuário do Instituto de Geociências, n. 41, v. 3 p. 470-482, 2018a. http://dx.doi.org/10.11137/20183470482

GOMES, C. H.; SPERANDIO, D. G.; DESSART, R. L.; GIUSTI, D. D. Detection and Evaluation of metals in soil under influence of mining by Dispersive Energy X-ray Fluorescence Spectrometry (EDXRF), Lavras do Sul/RS. Ciência e Natura, v. 40, n. e70, 2018b. https://dx.doi.org/10.5902/2179460X32289

GUERRA, D. L.; LEMOS, V. P.; ANGÉLICA, R. S.; AIROLDI, C.; VIANA, R. R. Aplicação de $\mathrm{Zr} / \mathrm{Ti}$-PILC no processo de adsorção Cu (II), Ni (II) e Co (II) utilizando modelos físico-químicos de adsorção. Química Nova, v.31, n.2, p.353-359, 2008. https://dx.doi.org/10.1590/S0100-40422008000200031

LAWRENCE, F. W.; UPCHURCH, S. B. Identification of Recharge Areas Using Geochemical Factor Analysis. Ground Water, n. 20, v. 6, p. 680-687, 1982. https://doi.org/10.1111/j.1745-6584.1982.tb01387.x

LINHAI JING, Q. C.; PANAHI, A. Principal component analysis with optimum order sample correlation coefficient for image enhancement. International Journal of Remote Sensing, v. 27, n. 16, p. 3387-3401, 2006. https://doi.org/10.1080/01431160600606882 
LOPES, R.W. Caracterização petrográfica e geoquímica da Mina do Seival, Bacia do Camaquã, RS. 80f. 2013. Tese (Doutorado em Geociências) - Universidade Federal do Rio Grande do Sul, Porto Alegre, 2013.

MARTIN, S.; GRISWOLD, W. Human health effects of heavy metals. Environmental Science \& Technology. n. 15 p. 1-6, 2009.

MUKAKA, M. M. A guide to appropriate use of correlation coefficient in medical research. Malawi Medical Journal, v. 24, n.3, p. 69-71, 2012.

PESTANA, M. H. D.; FORMOSO, M. L. L. Mercury contamination in Lavras do Sul, South Brazil: a legacy from past and recent gold mining. Science of the Total Environment, v. 307, 1-3, p. 125-140, 2003. https://doi.org/10.1016/S0048-9697(02)00535-1

PEREIRA, H. M.; LEADLEY, P. W.; PROENÇA, V.; ALKEMADE, R.; SCHARLEMANN, J. P. W.; FERNANDEZ-MANJARRES, J. F. Scenarios for global biodiversity in the 21st century. Science, v. 330, p. 1496-1501, 2010. http://dx.doi.org/10.1126/science.1196624

PIVELI, R. P.; KATO, M. T. Qualidade das águas e poluição: aspectos físico-químicos. São Paulo: ABES. 2006.

PORCHER, C. A.; LOPES, R. da C. Programa Levantamentos Geológicos Básicos do Brasil. Cachoeira do Sul, Folha SH. Brasília: CPRM, 2000.

REIMANN, C.; FILZMOSER, P.; GARRET, R. G.; DUTTER. R. Statistical Data Analysis Explained: Applied Environmental Statistics with R. [S.1.]: Wiley-Blackwell, 2008.

RIBEIRO, M. Geologia da quadrícula de Caçapava do Sul, Rio Grande do Sul, Brasil. Rio de Janeiro, 1966. (Divisão de Fomento da Produção Mineral, n. 127).

RIEUWERTS, J. S.; ASHMORE, M. R.; FARAGO, M. E.; THORNTON, I. The influence of soil characteristics on the extractability of $\mathrm{Cd}, \mathrm{Pb}$ and $\mathrm{Zn}$ in upland and moorland soils. Science of the total Environment, n. 366, p. 64-875, 2006. https://doi.org/10.1016/j.scitotenv.2005.08.023

RIMSTIDT, J. D.; CHERMAK, J.A.; GAGEN, P.M. Reactions of minerals with Fe(III) in acidic solutions. In: ALPERS, C. N.; BLOWES, D. W. (eds.). Environmental Geochemistry of Sulfide Oxidation. Washington, D.C.: ACS, 1994. p. 1-13.

SAWYER, C. N.; MCCARTY, P. L.; PARKIN, G. F. Chemistry for environmental engineering. New Delhi: Tata McGraw-Hill, 2000.

SCHEIB, A. J.; LEE, J. R.; BREWARD, N.; RIDING, J. B. Reconstructing flow paths of the middle Pleistocene British ice sheet in central-eastern England: The application of regional soil geochemical data. Proceedings of the Geologists' Association, v. 3, p. 432444, 2011. https://doi.org/10.1016/j.pgeola.2011.01.008

STEFFENS, C.; KLAUCK, C. R.; BENVENUTI, T.; SILVA, L. B.; RODRIGUES, M. A. S. Water quality assessment of the Sinos River - RS, Brazil. Brazilian Journal of Biology, v. 75, n. 4, Suppl. 2, p. 62-67, 2015. https://dx.doi.org/10.1590/1519-6984.01613suppl

SUBBARAO, G. V.; SAHRAWAT, K. L.; NAKAHARA, K.; ISHIKAWA, T.; KISHII, M.; RAO, I. M.; HASH, C. T.; GEORGE, T. S.; RAO P. S.; NARDI, P.; BONNETT, D.; BERRY, W.; SUENAGA, K.; LATA, J. C. Biological nitrification inhibition -A novel strategy to regulate nitrification in agricultural systems. Advances in Agronomy. v. 114, p. 249-306, 2012. https://doi.org/10.1016/B978-0-12-394275-3.00001-8 
TACK, F. M. G. Trace Elements: General Soil Chemistry, Principles and Processes. In: HOODA, P. S. (ed.). Trace Elements in Soil. [S.1.]: Wiley-Blackwell, 2010. p. 9-32.

TEIXEIRA, P. C.; DONAGEMMA, G. K.; FONTANA, A.; TEIXEIRA, W. G. Manual de Métodos de Análise de Solo. 3th ed. Brasília, DF: Embrapa; 2017.

WASTOWSKI, A. D.; DA ROSA, G. M.; CHERUBIN, M. R.; RIGON, J. P. G. Caracterização dos níveis de elementos químicos em solo, submetido a diferentes sistemas de uso e manejo, utilizando espectrometria de fluorescência de raios-X por energia dispersiva (EDXRF). Química Nova, v. 33, n. 7, p. 1449-1452, 2010. http://dx.doi.org/10.1590/S0100-40422010000700005 